\title{
Moryella indoligenes gen. nov., sp. nov., an anaerobic bacterium isolated from clinical specimens
}

\author{
Jean-Philippe Carlier, ${ }^{1}$ Guylène $\mathrm{K}^{\prime}$ ouas ${ }^{1}$ and Xiang Y. Han ${ }^{2}$ \\ ${ }^{1}$ Centre National de Référence des Bactéries Anaérobies et du Botulisme, Institut Pasteur, \\ 25 rue du Dr Roux, F-75724 Paris Cedex 15, France \\ ${ }^{2}$ Section of Clinical Microbiology, The University of Texas M.D. Anderson Cancer, 1515 \\ Holcombe Blvd, Houston, TX 77030, USA
}

\begin{abstract}
Three Gram-positive, anaerobic, non-spore-forming, rod-shaped bacteria with pointed ends were isolated from clinical specimens. The organisms were weakly saccharolytic and produced indole, acetate, butyrate and lactate as major metabolic end products. 16S rRNA gene sequence analysis indicated that the isolates had no known close relatives among recognized bacteria but that they exhibited a phylogenetic association with Clostridium rRNA cluster XIVa [as defined by Collins, M. D. et al. (1994). Int J Syst Bacterio/44, 812-826]. The closest recognized relatives were the type strains of Clostridium clostridioforme, Clostridium bolteae and Clostridium asparagiforme (16S rRNA gene sequence similarity values of 90.2-91.4\%). These results suggest that these three clinical isolates represent a novel species of a new genus, for which the name Moryella indoligenes gen. nov., sp. nov. is proposed. The type strain of Moryella indoligenes is AIP $220.04^{\top}$ $\left(=\mathrm{CIP} 109174^{\top}=\right.$ CCUG $\left.52648^{\top}\right)$.
\end{abstract}

Anaerobic bacteria constitute an important part of the human microbial community. Although the majority are considered to be commensals, many of them behave as opportunistic pathogens. Notwithstanding intensive investigations by using conventional identification techniques, we still know relatively little about the bacterial diversity of these microbial communities. Indeed, molecular genetic tools have indicated that $60-80 \%$ of organisms in the total human microflora have not been cultivated (Langendijk et al., 1995; Suau et al., 1999) and only $24 \%$ of the molecular species recovered from the human intestinal tract corresponded to recognized species (Suau et al., 1999). Thus, the combination of genetic tools and traditional phenotypic methods of identification should be used whenever possible with the aim of providing greater knowledge of these 'hidden' bacteria. Here we report on the characterization of an indole-producing anaerobic bacterium that was recovered from different clinical specimens. Phylogenetically, the strains described represent a hitherto unknown subline within the Clostridium coccoides rRNA group. Based on the data presented, we describe a novel species in a new genus for these strains.

The new isolates were recovered from clinical sources: strain AIP 241.03 from a buttock abscess, strain AIP $220.04^{\mathrm{T}}$ from

The GenBank/EMBL/DDBJ accession numbers for the 16S rRNA gene sequences of strains AIP 241.03, AIP $220.04^{\top}$ and MDA2477 are DQ377946, DQ377947 and AF527773, respectively. an intra-abdominal abscess (both from France) and strain MDA2477 from a polymicrobial thigh abscess (from Houston, TX, USA). Thus, these strains might all have originated from the intestinal tract. The strains were maintained in trypticase/glucose/yeast extract medium (TGY) consisting of $3 \%(\mathrm{w} / \mathrm{v})$ biotrypcase (bioMérieux), $0.5 \%$ glucose (Prolabo), $2 \%$ yeast extract (Difco), $0.05 \%$ L-cysteine hydrochloride (Prolabo) and $5 \mu \mathrm{g}$ haemin $\mathrm{ml}^{-1}$ (Calbiochem), under anaerobic conditions at $37^{\circ} \mathrm{C}$ for $24 \mathrm{~h}$ in an anaerobic jar containing $95 \% \mathrm{H}_{2}$ and $5 \% \mathrm{CO}_{2}(\mathrm{v} / \mathrm{v})$. Colony morphology determinations and presumptive identification tests (Engelkirk et al., 1992) were performed on Wilkins-Chalgren agar plates. Biochemical reactions were examined according to the procedures described by Holdeman et al. (1977). Metabolic end products were assayed by quantitative GC as described by Carlier (1985). For electron microscopy, cells were prepared as described by Carlier et al. (2004), and electron microphotographs were taken with a JEOL 1010 transmission electron microscope operating at $80 \mathrm{kV}$.

Colonies appeared on Wilkins-Chalgren blood agar after 24-48 h incubation. They were circular, convex, about $0.5-$ $1 \mathrm{~mm}$ in diameter, non-pigmented and non-haemolytic. Cells were elongated, sometimes warped rods with pointed ends, about $0.8-1.7 \mu \mathrm{m}$ long and $0.5-0.6 \mu \mathrm{m}$ wide, usually occurring singly, in pairs or occasionally in short chains (Fig. 1a). They were non-motile, Gram-variable after staining but structurally Gram-positive (Fig. 1b). Spore formation was not observed. 

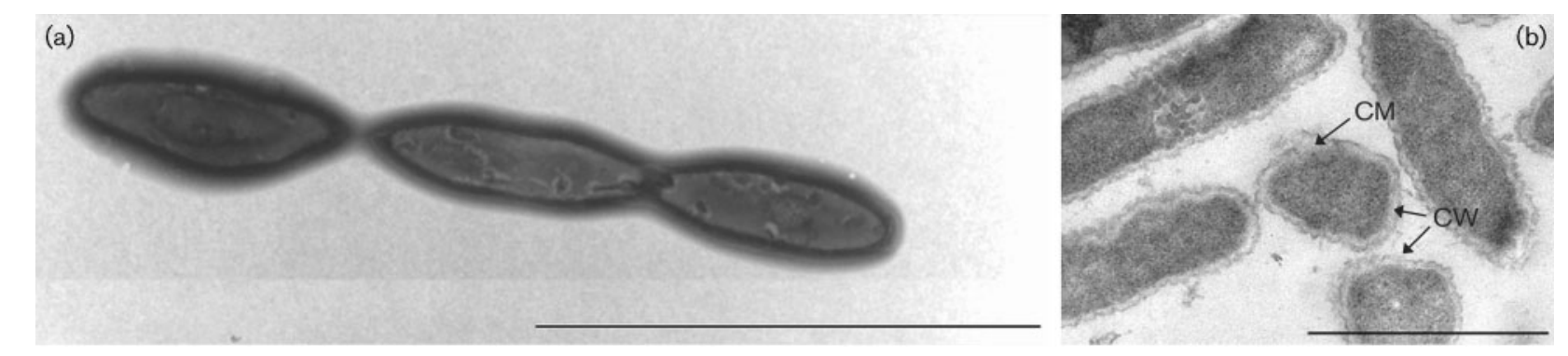

Fig. 1. Transmission electron micrographs of cells of strain AIP $220.04^{\top}$. (a) General morphology after negative staining; (b) ultrathin section showing the Gram-positive cell wall (CW) and cytoplasmic membrane (CM). Bars, $5 \mu \mathrm{m}$ (a) and $1 \mu \mathrm{m}$ (b).

The isolates were strictly anaerobic. They were susceptible to discs containing $1 \mathrm{mg}$ kanamycin, $10 \mu \mathrm{g}$ colistin, $5 \mu \mathrm{g}$ vancomycin and $4 \mu \mathrm{g}$ metronidazole and to bile discs. They were indole-positive. Catalase activity and nitrate and nitrite reduction were not detected. Gelatin was not liquefied and milk was not modified. Glucose, galactose, maltose and ribose fermentation were variable. Acid was not produced from raffinose, sucrose, aesculin, arabinose, cellobiose, fructose, glycerol, inositol, lactose, mannitol, mannose, melezitose, melibiose, rhamnose, salicin, sorbitol, starch, trehalose or xylose. Aesculin was not hydrolysed. The major metabolic end products were acetic acid (6.4-14 $\left.\mathrm{mmol} \mathrm{l}^{-1}\right)$, butyric acid (12-28 $\mathrm{mmol}^{-1}$ ) and lactic acid (6-25 mmol $\left.1^{-1}\right)$. Table 1 provides the primary characteristics of these isolates that can be used to differentiate them from several closely related species.

The $\mathrm{G}+\mathrm{C}$ composition of strain AIP $220.04^{\mathrm{T}}$ was $50.2 \mathrm{~mol} \%$, as determined by HPLC at the Identification Service of the DSMZ (German Collection of Microorganisms and Cell Cultures). Cellular fatty acid composition was analysed by GC according to Veys et al. (1989). Briefly, the three strains were grown anaerobically in $10 \mathrm{ml}$ TGY for $48 \mathrm{~h}$ and chromatography of the methyl esters was on a fused-silica capillary column $(25 \mathrm{~m} \times 0.25 \mathrm{~mm}$ ID) coated with $5 \%$ methyl phenyl silicone. Fatty acid methyl ester analysis showed that the strains contained an unknown compound that eluted between $\mathrm{C}_{12: 0}$ and $\mathrm{C}_{13: 0}(14 \%)$, $\mathrm{C}_{14: 0}(47 \%)$ and $\mathrm{C}_{16: 0}(9 \%)$ as the major components. Minor fatty acids included $\mathrm{C}_{12: 0}(3.4 \%)$, iso- $\mathrm{C}_{14: 0}(2.7 \%)$, iso- $\mathrm{C}_{15: 0}(2.4 \%)$, anteiso- $\mathrm{C}_{15: 0}(7 \%)$, a second unknown compound that eluted between $\mathrm{C}_{14: 0}$ and iso- $\mathrm{C}_{15: 0}(6.2 \%)$, iso- $\mathrm{C}_{16: 0}(1.4 \%), \mathrm{C}_{16: 1} \omega 9 c(2.6 \%)$ and $\mathrm{C}_{18: 0}(1.4 \%)$. No hydroxy fatty acids were detected.

The 16S rRNA gene sequences were determined for each strain as described by Carlier $e t$ al. (2004). Alignment was via the CLUSTAL W program (Thompson et al., 1994). Regions showing alignment uncertainties and gaps were excluded and 1375 unambiguous nucleotide positions were used. A distance matrix was calculated by using DNADIST with the Jukes-Cantor parameter (Jukes \& Cantor, 1969). A phylogenetic tree (Fig. 2) was constructed according to the neighbour-joining method with 100 bootstrap resamplings
(Felsenstein, 1993). Sequence comparison revealed that the new isolates shared more than $99.9 \%$ 16S rRNA gene sequence similarity with each other and had no known close relatives among recognized bacteria. Indeed, the nearest phylogenetic neighbours were the type strains of Clostridium clostridioforme, Clostridium bolteae and Clostridium asparagiforme, with sequence similarity values of $90.2-91.4 \%$. The new isolates formed a distinct lineage within the $C$. coccoides rRNA group of organisms, and the monophyly of this lineage was strongly supported by the high bootstrap value of $98 \%$. Thus, these isolates were considered to represent a novel taxon. Within the lineage, an oral clone MCE9_173 branched off; this clone, described by Munson et al. (2002) as 'Lachnospiraceae', shared $93.4 \%$ sequence similarity with the novel organism. To determine the genus and species status of the novel organism, its relationship with members of the C. coccoides rRNA cluster was examined. This cluster encompasses a phenotypically heterogeneous collection of organisms, including sporeforming and non-spore-forming genera and species. Several butyrate-producing members are also widely distributed within this cluster (Barcenilla et al., 2000). Although the novel bacterium was phylogenetically closer to the $C$. clostridioforme group, it differed from these clostridia because it was not a spore-former and produced butyrate. On the other hand, it was phylogenetically too distant from the butyrate-producing members to be assigned to those genera or species. Thus, given the $\sim 10 \% 16 \mathrm{~S}$ rRNA gene sequence divergence from their closest relatives and several distinct phenotypic features, the three strains are considered to represent a novel species of a new genus, for which the name Moryella indoligenes gen. nov., sp. nov. is proposed.

\section{Description of Moryella gen. nov.}

Moryella (Mo.ry.el'la. L. fem. dim. ending -ella; N.L. fem. n. Moryella named in honour of the French microbiologist Francine Mory, who has contributed to our understanding of anaerobes).

Cells are Gram-variable after staining but structurally Gram-positive, elongated, non-motile rods with pointed ends. Cells may lose their colour easily. No spores are formed. Strictly anaerobic, without growth under 
Table 1. Characteristics that differentiate the three new clinical strains from other close relatives

ND, Not determined/no data available; $v$, strain variation; d, 11-89\% of strains positive.

\begin{tabular}{|c|c|c|c|c|c|c|c|c|c|c|c|}
\hline Characteristic & AIP $220.04^{T}$ & AIP 241.03 & MDA2477 & $\begin{array}{c}\text { Oribacterium } \\
\text { sinus }\end{array}$ & $\begin{array}{l}\text { Lachnospira } \\
\text { multipara }\end{array}$ & $\begin{array}{l}\text { Lachnospira } \\
\text { pectinoschiza }\end{array}$ & $\begin{array}{c}\text { Butyrivibrio } \\
\text { crossotus }\end{array}$ & $\begin{array}{l}\text { Butyrivibrio } \\
\text { fibrisolvens }\end{array}$ & $\begin{array}{c}\text { Clostridium } \\
\text { clostridioforme }\end{array}$ & $\begin{array}{c}\text { Clostridium } \\
\text { bolteae }\end{array}$ & $\begin{array}{c}\text { Clostridium } \\
\text { asparagiforme }\end{array}$ \\
\hline Cell shape & $\begin{array}{l}\text { Elongated, } \\
\text { pointed } \\
\text { ends }\end{array}$ & $\begin{array}{l}\text { Elongated, } \\
\text { pointed } \\
\text { ends }\end{array}$ & $\begin{array}{l}\text { Elongated, } \\
\text { pointed } \\
\text { ends }\end{array}$ & Ovoid & Curved & Straight & Curved & Curved & Straight & Straight & $\begin{array}{l}\text { Straight, } \\
\text { tapered ends }\end{array}$ \\
\hline Motility & - & - & - & + & + & + & + & + & + & $\mathrm{ND}$ & ND \\
\hline Spore formation & - & - & - & - & - & $\begin{array}{l}\text { Spore-like } \\
\text { structures }\end{array}$ & - & - & + & + & + \\
\hline Indole & + & + & + & + & - & ND & $\mathrm{ND}$ & - & $\mathrm{v}$ & - & ND \\
\hline \multicolumn{12}{|l|}{ Acid from: } \\
\hline Lactose & - & - & - & - & - & + & d & + & $\mathrm{V}$ & - & ND \\
\hline Maltose & - & - & - & - & - & - & - & + & + & + & ND \\
\hline Metabolic end products ${ }^{*}$ & $\mathrm{~A}, \mathrm{~B}, 1$ & $\mathrm{a}, \mathrm{B}, \mathrm{L}$ & $\mathrm{A}, \mathrm{B}, \mathrm{L}$ & $\mathrm{A}, \mathrm{L}$ & $\mathrm{F}, \mathrm{A}, \mathrm{L}, \mathrm{e}$ & $\mathrm{F}, \mathrm{A}, \mathrm{e}$ & $\mathrm{F}, \mathrm{A}, \mathrm{B}, \mathrm{L}$ & $\mathrm{F}, \mathrm{B},(\mathrm{a}, \mathrm{l})$ & $\mathrm{A}$ & $\mathrm{A}, \mathrm{L}$ & $\mathrm{A}, \mathrm{L}, \mathrm{e}$ \\
\hline $\begin{array}{l}\text { DNA G }+ \text { C content } \\
(\mathrm{mol} \%)\end{array}$ & 50.2 & $\mathrm{ND}$ & $\mathrm{ND}$ & 42.4 & $\mathrm{ND}$ & 51.4 & $36-37$ & 41 & $47-49$ & 50.5 & 53 \\
\hline Isolation source & $\begin{array}{c}\text { Human } \\
\text { buttock } \\
\text { abscess }\end{array}$ & $\begin{array}{c}\text { Human intra- } \\
\text { abdominal } \\
\text { abscess }\end{array}$ & $\begin{array}{l}\text { Human } \\
\text { thigh } \\
\text { abscess }\end{array}$ & $\begin{array}{c}\text { Human } \\
\text { oral } \\
\text { cavity }\end{array}$ & $\begin{array}{l}\text { Rumen of } \\
\text { ruminants }\end{array}$ & Pig intestine & $\begin{array}{l}\text { Human } \\
\text { faeces }\end{array}$ & $\begin{array}{c}\text { Rumen of } \\
\text { ruminants; } \\
\text { human, rabbit, } \\
\text { horse faeces }\end{array}$ & $\begin{array}{l}\text { Humans } \\
\text { and } \\
\text { animals }\end{array}$ & $\begin{array}{l}\text { Human faeces, } \\
\text { blood, intra- } \\
\text { abdominal } \\
\text { abscess }\end{array}$ & $\begin{array}{l}\text { Human } \\
\text { faeces }\end{array}$ \\
\hline Reference & This paper & This paper & This paper & $\begin{array}{l}\text { Carlier et al. } \\
\text { (2004) }\end{array}$ & $\begin{array}{l}\text { Bryant } \\
(1986 a)\end{array}$ & $\begin{array}{l}\text { Cornick et al. } \\
\text { (1994) }\end{array}$ & $\begin{array}{l}\text { Bryant } \\
(1986 b)\end{array}$ & $\begin{array}{c}\text { Bryant } \\
(1986 b)\end{array}$ & $\begin{array}{l}\text { Cato et al. } \\
\text { (1986) }\end{array}$ & $\begin{array}{l}\text { Song et al. } \\
\quad(2003)\end{array}$ & $\begin{array}{l}\text { Mohan et al. } \\
\text { (2006) }\end{array}$ \\
\hline
\end{tabular}

${ }^{\star}$ A, Acetate; B, butyrate; E, ethanol; F, formate; L, lactate. Parentheses indicate variable production. Upper-case letters indicate major products. 


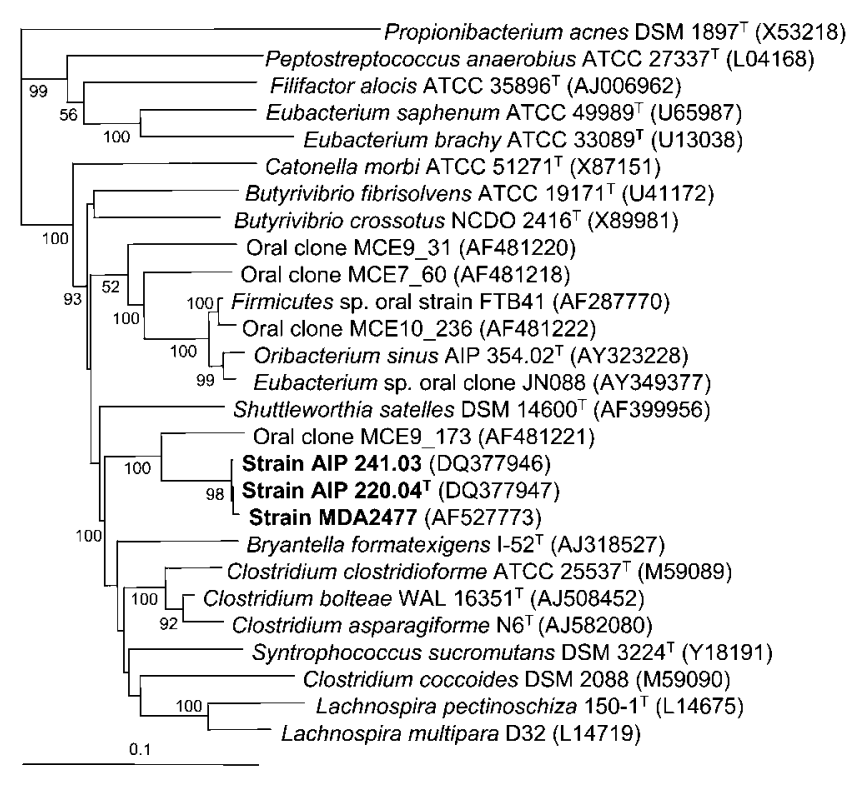

Fig. 2. Neighbour-joining phylogenetic tree based on $16 \mathrm{~S}$ rRNA gene sequence comparisons over 1375 aligned bases indicating the relationships between the three new clinical strains and related species. The sequence of Propionibacterium acnes DSM $1897^{\top}$ was used as an outgroup. Numbers on the tree are bootstrap percentages. GenBank accession numbers are given in parentheses. Bar, $10 \%$ sequence divergence.

microaerophilic or aerobic conditions. Catalase and urease reactions are negative. Nitrate is not reduced. Indolepositive and weakly saccharolytic. The major metabolic end products are acetic, butyric and lactic acids. Phylogenetically, the genus belongs to the C. coccoides rRNA cluster (rRNA cluster XIVa; Collins et al., 1994). The type species is Moryella indoligenes.

\section{Description of Moryella indoligenes sp. nov.}

Moryella indoligenes (in.do.li'ge.nes. N.L. n. indolum indole; N.L. suff. -genes producing from Gr. v. gennaô to produce; N.L. part. adj. indoligenes indole-producing).

Displays the following properties in addition to those given in the genus description. Cells are sometimes warped, about $0.8-1.7 \mu \mathrm{m}$ long and $0.5-0.6 \mu \mathrm{m}$ wide, occurring singly, in pairs or occasionally in short chains. Colonies are circular, convex and about $0.5-1 \mathrm{~mm}$ in diameter on WilkinsChalgren blood agar after $24-48 \mathrm{~h}$ incubation, nonpigmented and non-haemolytic. Indole production is the main biochemical characteristic of the species. Glucose, galactose, maltose and ribose fermentation are variable. Acid is not produced from any of the following carbohydrates: raffinose, sucrose, aesculin, arabinose, cellobiose, fructose, glycerol, inositol, lactose, mannitol, mannose, melezitose, melibiose, rhamnose, salicin, sorbitol, starch, trehalose or xylose. Aesculin is not hydrolysed. Gelatin is not liquefied and milk is not modified. The type strain is susceptible to ampicillin, amoxicillin, penicillin G, imipenem, cefalotin, cefotaxim, cefoxitin, latamoxef and metronidazole, moderately resistant to tetracycline and resistant to trimethoprimsulfamethoxazole, erythromycin and rifampicin. Strains AIP 241.03 and MDA2477 are resistant only to trimethoprimsulfamethoxazole and erythromycin. The DNA G+C content is $50.2 \mathrm{~mol} \%$. Habitat is not known, but likely to be the human gut.

The type strain, AIP $220.04^{\mathrm{T}}\left(=\mathrm{CIP} 109174^{\mathrm{T}}=\right.$ CCUG $\left.52648^{\mathrm{T}}\right)$, was isolated from a clinical specimen from an intra-abdominal abscess. Strains MDA2477 ( = ATCC BAA695) and AIP 241.03 are additional strains of this species.

\section{Acknowledgements}

We are grateful to M.-C. Prevost and A. Mallet (Plate-forme de Microscopie Electronique, Institut Pasteur, Paris) for performing the transmission electron microscopy.

\section{References}

Barcenilla, A., Pryde, S. E., Martin, J. C., Duncan, S. H., Stewart, C. S., Henderson, C. \& Flint, H. J. (2000). Phylogenetic relationships of butyrate-producing bacteria from the human gut. Appl Environ Microbiol 66, 1654-1661.

Bryant, M. P. (1986a). Genus XIII. Lachnospira Bryant and Small 1956, 24. In Bergey's Manual of Systematic Bacteriology, vol. 2, pp. 1375-1376. Edited by P. H. A. Sneath, N. S. Mair, M. E. Sharpe \& J. G. Holt. Baltimore: Williams \& Wilkins.

Bryant, M. P. (1986b). Genus IV. Butyrivibrio Bryant and Small 1956, 18 , emend. Moore, Johnson and Holdeman 1976, 241 ${ }^{\mathrm{AL}}$. In Bergey's Manual of Systematic Bacteriology, vol. 2, pp. 1376-1379. Edited by P. H. A. Sneath, N. S. Mair, M. E. Sharpe \& J. G. Holt. Baltimore: Williams \& Wilkins.

Carlier, J.-P. (1985). Gas chromatography of fermentation products: its application in diagnosis of anaerobic bacteria. Bull Inst Pasteur 83, 57-69.

Carlier, J.-P., K'ouas, G., Bonne, I., Lozniewski, A. \& Mory, F. (2004). Oribacterium sinus gen. nov., sp. nov., within the family 'Lachnospiraceae' (phylum Firmicutes). Int J Syst Evol Microbiol 54, 1611-1615.

Cato, E. P., George, W. L. \& Finegold, S. M. (1986). Genus Clostridium Prazmowski 1880, 23. In Bergey's Manual of Systematic Bacteriology, vol. 2, pp. 1141-1200. Edited by P. H. A. Sneath, N. S. Mair, M. E. Sharpe \& J. G. Holt. Baltimore: Williams \& Wilkins.

Collins, M. D., Lawson, P. A., Willems, A., Cordoba, J. J., FernandezGarayzabal, J., Garcia, P., Cai, J., Hippe, H. \& Farrow, J. A. (1994). The phylogeny of the genus Clostridium: proposal of five new genera and eleven new species combinations. Int J Syst Bacteriol 44, 812-826.

Cornick, N. A., Jensen, N. S., Stahl, D. A., Hartman, P. A. \& Allison, M. J. (1994). Lachnospira pectinoschiza sp. nov., an anaerobic pectinophile from the pig intestine. Int J Syst Bacteriol 44, 87-93.

Engelkirk, P. G., Duben-Engelkirk, J. \& Dowell, V. R. (1992). Principles and Practice of Clinical Anaerobic Bacteriology. Belmont, CA: Star Publishing.

Felsenstein, J. (1993). PHYLIP (phylogeny inference package), version 3.5c. Department of Genome Sciences, University of Washington, Seattle, USA.

Holdeman, L. V., Cato, E. P. \& Moore, W. E. C. (1977). Anaerobe Laboratory Manual, 4th edn. Blacksburg, VA: Virginia Polytechnic Institute and State University. 
Jukes, T. H. \& Cantor, R. R. (1969). Evolution of protein molecules. In Mammalian Protein Metabolism, pp. 21-132. Edited by $\mathrm{H}$. N. Munro. New York: Academic Press.

Langendijk, P. S., Schut, F., Jansen, G. J., Raangs, G. C., Kamphuis, G. R., Wilkinson, M. H. \& Welling, G. W. (1995). Quantitative fluorescence in situ hybridization of Bifidobacterium spp. with genusspecific $16 \mathrm{~S}$ rRNA-targeted probes and its application in fecal samples. Appl Environ Microbiol 61, 3069-3075.

Mohan, R., Namsolleck, P., Lawson, P. A., Osterhoff, M., Collins, M. D., Alpert, C.-A. \& Blaut, M. (2006). Clostridium asparagiforme sp. nov., isolated from a human faecal sample. Syst Appl Microbiol 29, 292-299.

Munson, M. A., Pitt-Ford, T., Chong, B., Weightman, A. \& Wade, W. G. (2002). Molecular and cultural analysis of the microflora associated with endodontic infections. J Dent Res 81, 761-766.
Song, Y., Liu, C., Molitoris, D. R., Tomzynski, T. J., Lawson, P. A., Collins, M. D. \& Finegold, S. M. (2003). Clostridium bolteae sp. nov., isolated from human sources. Syst Appl Microbiol 26, 84-89.

Suau, A., Bonnet, R., Sutren, M., Godon, J.-J., Gibson, G. R., Collins, M. D. \& Doré, J. (1999). Direct analysis of genes encoding 16S rRNA from complex communities reveals many novel molecular species within the human gut. Appl Environ Microbiol 65, 4799-4807.

Thompson, J. D., Higgins, D. G. \& Gibson, T. J. (1994). CLUSTAL W: improving the sensitivity of progressive multiple sequence alignment through sequence weighting, position-specific gap penalties and weight matrix choice. Nucleic Acids Res 22, 4673-4680.

Veys, A., Callewaert, W., Waelkens, E. \& Van den Abbeele, K. (1989). Application of gas-liquid chromatography to the routine identification of nonfermenting Gram-negative bacteria in clinical specimens. J Clin Microbiol 27, 1538-1542. 